\title{
Postoperative infected organised subdural haematoma that necessitated wide craniotomy
}

\author{
Tokunori Kanazawa 주, Kosuke Karatsu, Takumi Kuramae, Masayuki Ishihara
}

Department of Neurosurgery, National Hospital Organisation Tochigi Medical Center, Utsunomiya, Japan

\section{Correspondence to} Dr Tokunori Kanazawa; norinori0128jp@yahoo.co.jp

Accepted 25 June 2021

\section{DESCRIPTION}

A 79-year-old man presented to our department with a slight fever. His medical history included cardiogenic brain embolism, atrial fibrillation and refractory chronic subdural haematoma (SDH). He had undergone two operations for chronic SDH 3 months before this admission (first surgery: burr hole drainage; second surgery: burr hole drainage in conjunction with middle meningeal artery (MMA) embolisation). Clinical examination revealed no limb paralysis. A routine laboratory examination demonstrated elevations in the leucocyte count $\left(10.4 \times 10^{9} / \mathrm{L}\right)$ and serum $C$ reactive protein level $(2.68 \mathrm{mg} / \mathrm{dL})$. Head CT revealed a large hypodense lesion with right-sided midline shift along the left cerebral convexity (figure 1A). On T2-weighted MRI, the lesion exhibited mixed intensity with a peripheral rim of hypointensity but no surrounding oedema (figure 1B). Diffusion-weighted imaging revealed high signal intensity in the same region (figure 1C). Because infected SDH was suspected, large craniotomy was performed (figure $2 \mathrm{~A}, \mathrm{~B}$ ) and the infected haematoma capsule was completely removed (figure 2C). Head CT performed 24 hours after the operation showed complete disappearance of the infected SDH and a minor postoperative haemorrhage (figure 1D). No bacteria were identified from a culture of the purulent specimen. The patient was treated with ceftazidime, vancomycin and metronidazole for the next 6 weeks and then discharged without neurologic deficits. All the results of routine laboratory tests including

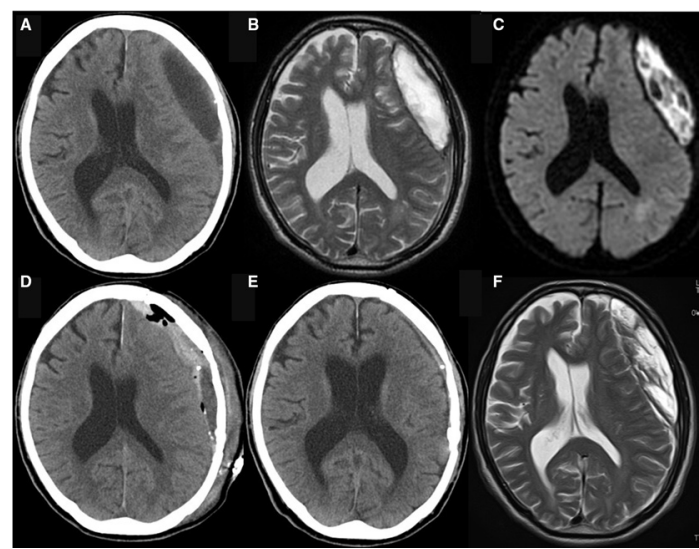

Figure 1 (A) Head CT on admission. (B) T2-weighted imaging on admission. (C) Diffusion-weighted imaging on admission. (D) Head CT 24 hours after removal of infected subdural haematoma (SDH). (E) Head CT 6 months after the removal of infected SDH. (F) T2-weighted imaging before the second surgery.

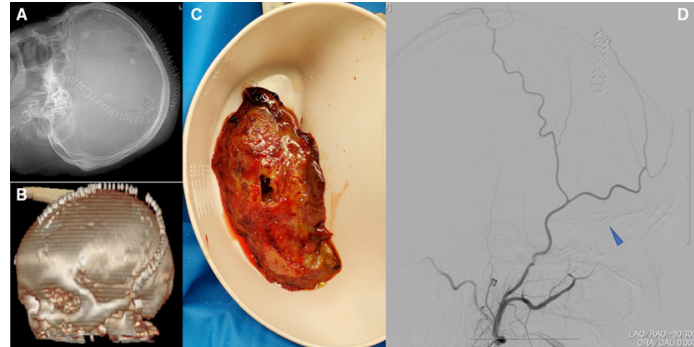

Figure 2 (A) Head X-ray after removal of infected subdural haematoma (SDH). (B) Bone CT after the removal of infected SDH. (C) Intraoperative photograph showing total removal of infected subdural haematoma (SDH). (D) External carotid angiography after embolisation. The left middle meningeal artery (MMA) was completely embolised with $\mathrm{N}$-butyl-2-cyanoacrylate (blue arrow).

complete blood count and inflammatory markers were within normal limits at discharge. Follow-up CT 6 months after haematoma removal revealed no recurrent lesions (figure $1 \mathrm{E}$ ).

Infected SDH is rare. The organisms associated with infected SDH vary and depend on the source of infection; therefore, infected SDH can result from sinusitis, otitis, meningitis, bacterial translocation or previous surgery. ${ }^{1}{ }^{2}$ In this case, no causative organisms were identified because the wound infection had been treated with oral antibiotics. As a result of the increasing frequency of cranial surgery, postoperative infection often leads to infected SDH. ${ }^{3}$ According to a previous report, ${ }^{4}$ the membrane of chronic SDH is a potential site of infection because it contains rich vascular capillary beds. In this case, MMA embolisation was performed to prevent recurrences of chronic SDH (figure 2D). However, because part of the haematoma was organised (figure $1 \mathrm{~F}$ ), the development of new collateral vascular pathways in the outer membrane of the haematoma might have contributed not only to the recurrence but also to the infection. ${ }^{5}$ Therefore, in chronic SDH with partially organised haematoma, MMA embolisation may not

\section{Patient's perspective}

Daughter: 'We were informed and agreed that my father had infected SDH and underwent large craniotomy. We were relieved to confirm the disappearance of the infected SDH and improvement in symptoms. After discharge, he was fine, without fever.' 


\section{Learning points}

- We used wide craniotomy to treat a case of infected subdural haematoma (SDH) that recurred after two operations.

- If chronic SDH with partially organised haematoma recurs, then middle meningeal artery embolisation should not be performed.

- In the treatment of infected SDH, wide craniotomy enables total removal of the infection focus and improves clinical outcomes.

be effective, which can result in infected SDH. The treatment of infected SDH remains controversial ${ }^{6}$; however, we recommend a wide craniotomy because it ensures total removal of the membrane and vascular network of the chronic SDH-a potential focus for bacterial infection-and produces better clinical outcomes.

Contributors Study concept or design: TKa. Data collection: TKa. Data analysis or interpretation: TKa. Writing the paper: TKa. Management of this patient: KK and
TKa. Supervisor: TKu and MI. All authors have critically reviewed the manuscript and approved the final version of the manuscript.

Funding The authors have not declared a specific grant for this research from any funding agency in the public, commercial or not-for-profit sectors.

Competing interests None declared.

Patient consent for publication Obtained.

Provenance and peer review Not commissioned; externally peer reviewed.

\section{ORCID iD}

Tokunori Kanazawa http://orcid.org/0000-0002-6191-1209

\section{REFERENCES}

1 Greenlee JE. Subdural empyema, 2003.

2 Gupta S, Vachhrajani S, Kulkarni AV, v KA, et al. Neurosurgical management of extraaxial central nervous system infections in children. J Neurosurg Pediatr 2011;7:441-51.

3 Tsai Y-D, Chang W-N, Shen C-C, et al. Intracranial suppuration: a clinical comparison of subdural empyemas and epidural abscesses. Surg Neurol 2003;59:191-6.

4 Aoki N, Sakai T, Oikawa A, et al. Infected subdural effusion associated with resolving subdural hematoma--case report. Neurol Med Chir 1997;37:637-9.

5 Chihara $\mathrm{H}$, Imamura $\mathrm{H}, \mathrm{Ogura} \mathrm{T}$, et al. Recurrence of a refractory chronic subdural hematoma after middle meningeal artery embolization that required craniotomy. NMC Case Rep J 2014;1:1-5.

6 Dabdoub CB, Adorno JO, Urbano J, et al. Review of the management of infected subdural hematoma. World Neurosurg 2016;87:663.e1-663.e8.

Copyright 2021 BMJ Publishing Group. All rights reserved. For permission to reuse any of this content visit

https://www.bmj.com/company/products-services/rights-and-licensing/permissions/

BMJ Case Report Fellows may re-use this article for personal use and teaching without any further permission.

Become a Fellow of BMJ Case Reports today and you can:

- Submit as many cases as you like

- Enjoy fast sympathetic peer review and rapid publication of accepted articles

- Access all the published articles

- Re-use any of the published material for personal use and teaching without further permission

Customer Service

If you have any further queries about your subscription, please contact our customer services team on +44 (0) 2071111105 or via email at support@bmj.com.

Visit casereports.bmj.com for more articles like this and to become a Fellow 